\title{
Turkey's Geopolitical Role: The Energy AngLe
}

\author{
Ali Tekin, Iva Walterova
}

Dr. Tekin is an assistant professor of International Relations at Bilkent

University, Ankara. Ms. Walterova is a graduate student at the Department

of International Relations, Bilkent University.

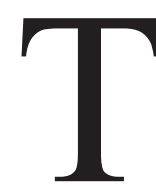

urkey has historically been of great geopolitical importance to states in the regions surrounding remotely located. As a member of NATO during the Cold War it was a geopolitical asset to the Western bloc as a strong ally in close proximity to the Soviet Union. With the fall of the Warsaw Pact, this consideration disappeared. However, Turkey has regained its geopolitical importance for other reasons. One of these is its location between large energy markets and major energy producers. Though it lacks its own significant mineral reserves, ${ }^{1}$ it has strategic advantages for energy transit as it lies between the Middle East, Russia and the Caucasus and the large energy markets of Europe and the West.

Many believe that having control over energy-transport corridors could be almost as essential as having control over energy supplies themselves. ${ }^{2}$ With its geostrategic position between important energy suppliers and consumers, Turkey can create a powerful role for itself in the global energy market. Turkey and other global actors have been working towards strengthening the country's role as an energy hub, aggregator and transit corridor in its region. ${ }^{3}$ The Baku-Tbilisi-Ceyhan (BTC) pipeline carrying oil from the Caspian to the Mediterranean opened in July 2006, ${ }^{4}$ and many other projects, including the Nabucco pipeline, which would supply Caspian gas to the EU, bypassing Russia, ${ }^{5}$ are under serious consideration. Through such initiatives, Turkey can not only gain energy security for itself, but also contribute to global energy security.

\section{ENERGY TO CONSUMING REGIONS}

\section{The European Union}

Until recently there has been no significant common policy regarding the security of energy and energy imports in the European Union. Over the last several years, many in the EU have started to become aware of the security dangers of such a policy gap. A Green Paper published in November 2000 by the European Commission pointed out the shortcomings of the EU's behavior and initiated a serious debate on the need for a "secure" supply of energy. ${ }^{6}$ A more recent Green Paper goes further, proposing that all member states agree on a strategic objective in

Journal Compilation (C) 2007, Middle East Policy Council 
terms of energy that would satisfy "...the need for the EU as a whole to have an energy mix that, overall, meets its core energy objectives."

According to the recent Paper, the EU's dependence on external energy has been increasing constantly. ${ }^{8}$ As the world's largest energy consumer without its own significant energy reserves, the Union is today one of the world's fastest-growing energy markets and the biggest energy importer. ${ }^{9}$ The 25 EU member states depend for about 80 percent of their energy consumption on fossil fuels (oil, natural gas and coal). About 50 percent of their oil and natural gas requirements are imported, and experts predict that this number will rise to 70 percent by $2030 .{ }^{10}$ Imports of natural gas will rise to 80 percent over the coming 25 years. ${ }^{11}$

These import figures clearly demonstrate that energy resources inside the EU are limited. According to the European Commission, extraction costs in the Union are high and the scarce domestic sources that the EU has are running out. ${ }^{12}$ Domestic oil resources, for example, are moving towards exhaustion; ${ }^{13}$ renewables, which could become a significant domestic resource of energy in the EU, will need significant investments and substantial policy efforts in order to do so. ${ }^{14}$ Therefore, the EU as a whole cannot expect domestic energy production to contribute to fulfilling its energy needs under the current circumstances.

This situation makes the EU vulnerable, particularly due to its economic dependence on certain types of energy, such as oil and gas, and on particular exporting countries. ${ }^{15}$ Currently, the Union imports 40 percent of its external natural gas from Russia and 45 percent of its imported oil from the OPEC Middle East countries. ${ }^{16}$ The European Commission states that the security of supply should not be realized maximizing energy selfsufficiency or reducing EU dependence. The policy towards security of supply should rather aim at minimizing the risks associated with EU energy dependence "by balancing between and diversifying various sources of supply (by product and by geographical region)." ${ }^{17}$

In terms of diversifying its energy sources, the Union's options are rather limited due to the lack of feasible alternative sources. The policy of diversifying energy imports can also bring only limited results. The world's remaining oil reserves will be increasingly concentrated in the Middle East; ${ }^{18}$ major natural gas reserves are located in only a few regions from which the production and transport costs are economically viable for the Union: Russia, the Caspian region, the Near East and Nigeria. ${ }^{19}$ Since Turkey borders most of these regions on one side and the EU on the other, it could provide for greater energy security by becoming another vital import route into the Union.

According to Roberts, 10 producers, with 35.5 percent of global gas reserves, are or might potentially be interested in using Turkey as a transit country to the EU. Thus the country's role in the Union's gas import market will remain great. Although Turkey plays a role in the global oil market as well, its role as a transit country for the EU market is important rather than vital. ${ }^{20}$ According to these conclusions, Turkey is of major geopolitical importance to the EU. ${ }^{21}$ It can be vital in the relations between the EU and many of its energy suppliers and could constitute an option towards greater diversification of export routes to the Union and therefore more energy security. 
Middle East Policy, Vol. XIV, No. 1, Sring 2007

\section{The United States}

Like the EU, the United States faces energy security risks. It recognizes that its growing dependence on imported energy is a security threat and that a policy to reduce this threat is necessary. ${ }^{22}$ According to the Energy Policy Development Group, "America in the year 2001 face[d] the most serious energy shortage since the oil embargoes of the 1970s." 23 The Group projects that over the next 20 years, U.S. oil consumption will increase by 33 percent and its consumption of natural gas will increase 50 percent. Although the use of oil has fallen by about 20 percent since 1970s, oil today is the largest source of primary energy in the United States, accounting for about 40 percent of American energy needs. ${ }^{24}$ The United States has been a net importer of oil since the 1950s, and today oil accounts for 89 percent of net U.S. energy imports. ${ }^{25}$

Unlike the EU, the United States has substantial domestic energy resources. America is the world's second-largest natural-gas producer and its third-largest oil producer. However, it imports more than half of the oil it consumes. ${ }^{26}$ These numbers demonstrate that the United States, although a large energy producer itself, faces problems because of its dependence on foreign producers and the narrow range of energy options. The longterm solution to these problems in the United States, as in the EU, is more supplier diversification, "not only for energy security but also for national security." 27

Although the United States is the second-largest importer of energy, ${ }^{28}$ it seems to be facing a lesser threat in terms of import dependency than the EU. First, it was importing only 24 percent of its energy resources in 2002, ${ }^{29}$ a much lower share than the EU's 50 percent. Second, the four largest suppliers of oil to the United States are Canada, Saudi Arabia, Venezuela and Mexico, which together account for 55 percent of U.S. gross imports. Due to geographic proximity, free-trade agreements, integrated pipeline networks or reciprocal energy-sector investments, ${ }^{30}$ the United States has good diplomatic and economic relations with at least three of them and therefore faces a lesser threat. Despite this fact, the threat exists, and the United States is unlikely to be able to mitigate it by domestic policies. The recommendation of the National Energy Policy Development Group was to "build strong relationships with energy-producing nations" and "to restore America's credibility overseas." $"$ It is therefore necessary that energy security and, consequently, supplier diversification become priorities of U.S. trade and foreign policy. ${ }^{32}$ Turkey can in some ways be instrumental in these efforts.

The U.S. administration has highlighted the role of Turkey as an energy hub and especially as a crucial link between Caspian and Central Asian energy reserves and world markets. In its efforts to promote Turkey's role, Washington emphasizes its own importance in supporting the cooperation of Turkey and the EU in energy security matters. ${ }^{33}$ On the other hand, the United States promotes Turkey's reliability as a dependable conduit for landlocked Caspian energy resources for itself. Turkey can help the United States attain its goal of resource diversification. ${ }^{34}$

Unlike the EU, the United States has pursued a coherent and unified foreign energy policy for many decades. Throughout the Cold War, the United States supplied military training and arms and 
established military bases in oil-rich regions in the Persian Gulf and Africa, ${ }^{35}$ as well as in Turkey. After the collapse of the Soviet Union, the United States has seen no reason to pursue such policies further; the main competitor has disappeared. However, as threats posed by newly emerging powers such as China and Russia grew throughout the 1990s, the United States returned to such policies and is now extending its military aid to states in the Caspian Basin as well. ${ }^{36}$ Simultaneously, Washington has also begun to promote greater economic and political cooperation with Turkey. ${ }^{37}$

After the end of the Cold War, the United States tried to establish military connections with the newly independent states in the region so that U.S. firms could comfortably invest there. America also strongly promoted its ideas as to where new infrastructure should be built. Because this was a matter of national security, ${ }^{38}$ U.S. leaders at the highest levels have been personally involved in negotiations with local powers. An instance of such behavior occurred when President Clinton oversaw the signing of an agreement for the BTC pipeline in 1999, a pipeline now transporting oil from Baku, Azerbaijan, to the Turkish port Ceyhan, from which oil can be shipped to Western markets. On the military side, some see the war in Afganistan and the ongoing deployment of U.S. military forces in Kyrgystan and Uzbekistan and American military advisors in Georgia for the protection of infrastructure and related matters as a way for the United States to gain military control over the Caspian and the Caucasus before others can. Military control and aid are, of course, major tools for promoting American interests in the region. ${ }^{39}$ All these efforts to increase United States energy security depend on the cooperation of
Turkey, apparently the most secure and preferred transit route from this region, when compared to Iran or Russia. From the energy angle, Turkey is therefore of substantial geopolitical importance to the United States, although perhaps not as important as it is to the EU.

\section{TURKEY AND PRODUCING REGIONS}

Turkey is geopolitically important to energy producers as well. The energymarket instability that could be created by the concentration of global production in a few regions benefits neither consumers nor producers. ${ }^{40}$ Due to the small number of major producers, any deliberate policy efforts or instability in producing regions are likely to increase price volatility, which has adverse impacts on both consumers and producers. Since Turkey has the potential as a transit country to increase the geographic diversification of energy resources to the West, it is important in helping to contain price volatilities.

\section{The Caspian Basin}

The Caspian Basin consists of parts of Russia, Kazakhstan, Turkmenistan, Iran, ${ }^{41}$ Azerbaijan and Uzbekistan. ${ }^{42}$ With the exception of Iran, this region was under full control of the former USSR until 1989. Although Moscow knew that there were significant reserves in this region, it decided to redirect its oil investments elsewhere in the mid-1970s. ${ }^{43}$ Under the Soviet Union, the Caspian was therefore a region with underdeveloped infrastructure and export routes; the only export routes went though Russia, though with insufficient capacity.

After gaining independence, some countries in the region found it undesirable to let Russia have full power over their exports 
and, therefore, prices. Because Turkey borders this region, it automatically became an alternative to Russia. The Russian monopoly has been undermined by the BTC oil pipeline that became operational in 2006 and the Baku-Tbilisi-Erzurum (Shah Deniz) gas pipeline currently under construction. Both of these pipelines connect the Caspian with Turkey. Although some of the Caspian countries have the possibility of exporting to the East and circumventing Russia, Turkey represents a possible important route to the large Western markets. Therefore, Turkey is of great geopolitical importance to the Caspian region.

Some of these countries should be able to gain greater profits from their resources and also strengthen their sovereignty and stability. ${ }^{44}$ In their efforts to diversify their energy resources, which include promoting the Turkish route from the Caspian, both the EU and the United States have been investing in the region. Some investments aim at developing the region's energy resources alone, while others - coming especially from the EU - have aimed at providing aid and supporting economic, social and political development.

The West also has security interests in the Caspian. The EU and the United States are interested in the resolution of local "frozen" conflicts, which lead to instability in the region as a whole as well as to activities such as trafficking, corruption ${ }^{45}$ or the possibility of manipulation of developments in the region by other great powers. Various authors point out, for example, that Russia has some involvement in the conflicts in Nagorno-Karabakh and South Ossetia and can rekindle them, causing difficulties for the continuing development of energy infrastructure in the region. ${ }^{46}$ Believing in the importance of military strength, the United States continues to promote its own goals, and Western goals in general, by military rivalry in the Caspian with other powers, such as China or Iran. Therefore, due to its resource wealth and the battle over the location of export routes, the region has also become a scene of the "Great Game" waged between major world powers over energy resources. This could have negative consequences, instability being the most likely.

\section{Russia}

Another major energy producer bordering on Turkey is Russia. As its largest export and the most significant source of foreign exchange, energy plays a major role in the Russian political economy. Russia is the third-largest producer of oil in the world and one of the world's largest natural-gas producers. Russia is selfsufficient in terms of energy, which is important for the country's future possibilities for growth and development. However, its great energy wealth and the legacy of Soviet central planning have also led Russia to become one of the most energyinefficient countries in the world, ${ }^{47}$ needing as much as 8.5 units of energy consumed to produce 1 unit of GDP. For the same purposes, the EU needs only 1 unit of energy, and China 6.5 units. $^{48}$

Nevertheless, Russia still manages to produce surplus energy resources, exporting 30 percent of its energy production. ${ }^{49}$ Over the last several years, the Russian economy has grown impressively, a growth fueled primarily by revenues from energy exports. The revenues from the Russian oil and gas sectors are estimated to have accounted for 25 percent of Russia's GDP in $2003 .{ }^{50}$ However, its heavy dependence 
on energy exports causes its economy to be vulnerable to even minor fluctuations in world energy prices. The great importance of energy also causes the state to attempt to influence the energy sector. Moscow has been preventing the liberalization of the Russian energy market and has nationalized parts of the energy sector, creating monopolies in natural gas and electricity. ${ }^{51}$

Compared to Russia, Turkey stands in an entirely different relationship to the Caspian. Because of its geographical position, Russia could potentially export energy to the Western markets (including Israel) through Turkey. However, unlike the Caspian, Russia borders the EU, has access to international ports and is an established and significant exporter to the West. Russia also possesses infrastructure to bring energy resources from the Caspian into Russia. Turkey is, therefore, more likely to compete with Russia for the transit of Caspian exports than to become its energy transit route. Adding to Turkey's disadvantage is the fact that it is largely dependent on Russia for its own naturalgas imports. It took more than half its gas imports from Russia in 2004. ${ }^{52}$

Turkey and Russia have been historic rivals. The Ottoman and Russian empires competed for regional supremacy; later, Turkey was the front-line NATO state in the Cold War against the Soviet Union. Although trade and diplomatic and political relations between the two have improved greatly since the end of the Cold War, the rivalry continues, particularly in relation to energy, as the two countries struggle over pipeline routes and influence in neighboring regions, including the Caspian Basin. ${ }^{53}$ Although involved on different sides of regional conflicts in the Caspian, both Russia and Turkey claim to be willing to continue the peace process in this region. ${ }^{54}$ Both sides are also putting effort into expanding bilateral energy trade. ${ }^{55}$ The Blue Stream pipeline bringing gas from Russia to Turkey is an example.

Although Turkey displays goodwill and tries to avoid taking sides in any "Russia vs. the West" struggle, ${ }^{56}$ rivalries over energy pipelines continue. How far Russia can go in its efforts to monopolize the European market and monopsonize Caspian exports depends largely on energy consumers. Some experts suggest that Gazprom, Russia's dominant energy company, would be able to stifle any competition and fulfill the needs of the Balkans and large parts of the European energy market, thereby shutting Turkey out of many gas-transit possibilities. Although Gazprom has taken some major steps in the direction of preventing third countries from having access to the European gas market without Russian control, ${ }^{57}$ it is unlikely to shut off its competition entirely ${ }^{58}$ for political and financial reasons.

A Gazprom monopoly in the European market is directly in conflict with the Western policy of diversification. The dangers of the power of this monopoly have come to the attention of the West, particularly the EU, in recent months, when Russia cut off natural-gas supplies to Ukraine, which wholly depends on Russia and is also a transport country to the EU. Therefore, the EU has a major interest in reducing the power of Gazprom in its market. In its Green Paper, the European Commission points out that the Union "should keep a watchful eye" 59 on the development and direction of export routes from the Caspian.

The United States supports the EU's interests in natural gas and promotes the 
Middle East Policy, Vol. XIV, No. 1, Sring 2007

\section{Figure 1}

\section{Persian Gulf Exports by Country - 2003}

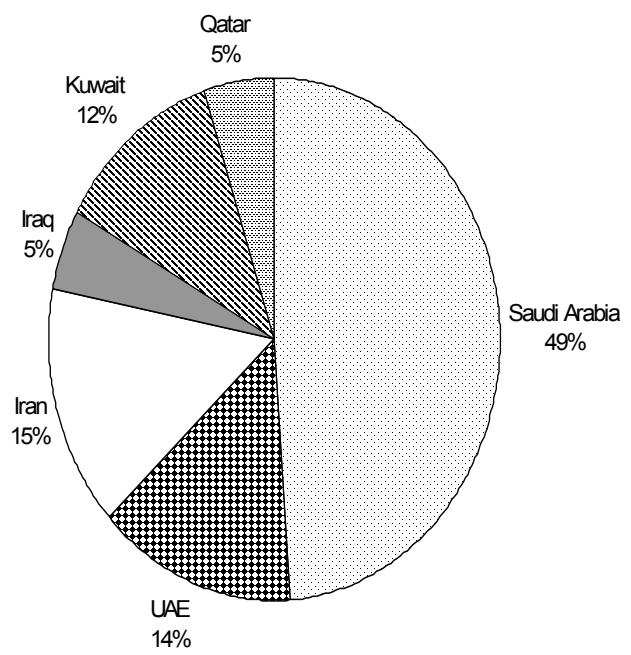

Source: A. Necdet Pamir, “Turkey's Energy Policies between East and West," presentation on February 21, 2006, Bilkent University, http://www.bilkent.edu.tr/ crs/necdetpamir.ppt.

interests of all Western consumers with relation to oil. As discussed above, Washington sees the diversification of energysupplying and transit regions as a matter of national security. The United States therefore strongly supports the development of a Turkish transit route from the Caspian as an alternative or an addition to the Russian route. ${ }^{60}$

Western consumers support Turkey as an alternative route from the Caspian to create competition to Gazprom and Russia overall; ${ }^{61}$ some Caspian producers also perceive Turkey as a better transit country for their exports. This fuels the rivalry between Russia and Turkey in the energy field and forces Russia to take into consideration the importance of Turkey in the geopolitics of the region.

\section{Middle East}

For the energy-rich Middle East region, Turkey can be geopolitically significant as a possible energy export transit route to the West. However, most of the Middle East has well-established infrastructure. The countries of the Middle East posses 61.7 percent of the world's recoverable oil reserves and 40.6 percent of recoverable natural-gas reserves, ${ }^{62}$ by far the largest of any region in the world.

The largest exporters in the Middle East are the countries around the Persian Gulf. As of 2003, Saudi Arabia was the largest energy exporter, accounting for almost 50 percent of overall Persian Gulf exports. Iran exports 15 percent, and the UAE 14 percent, of overall Persian Gulf exports. Iraq makes up 5 percent of these 
Figure 2

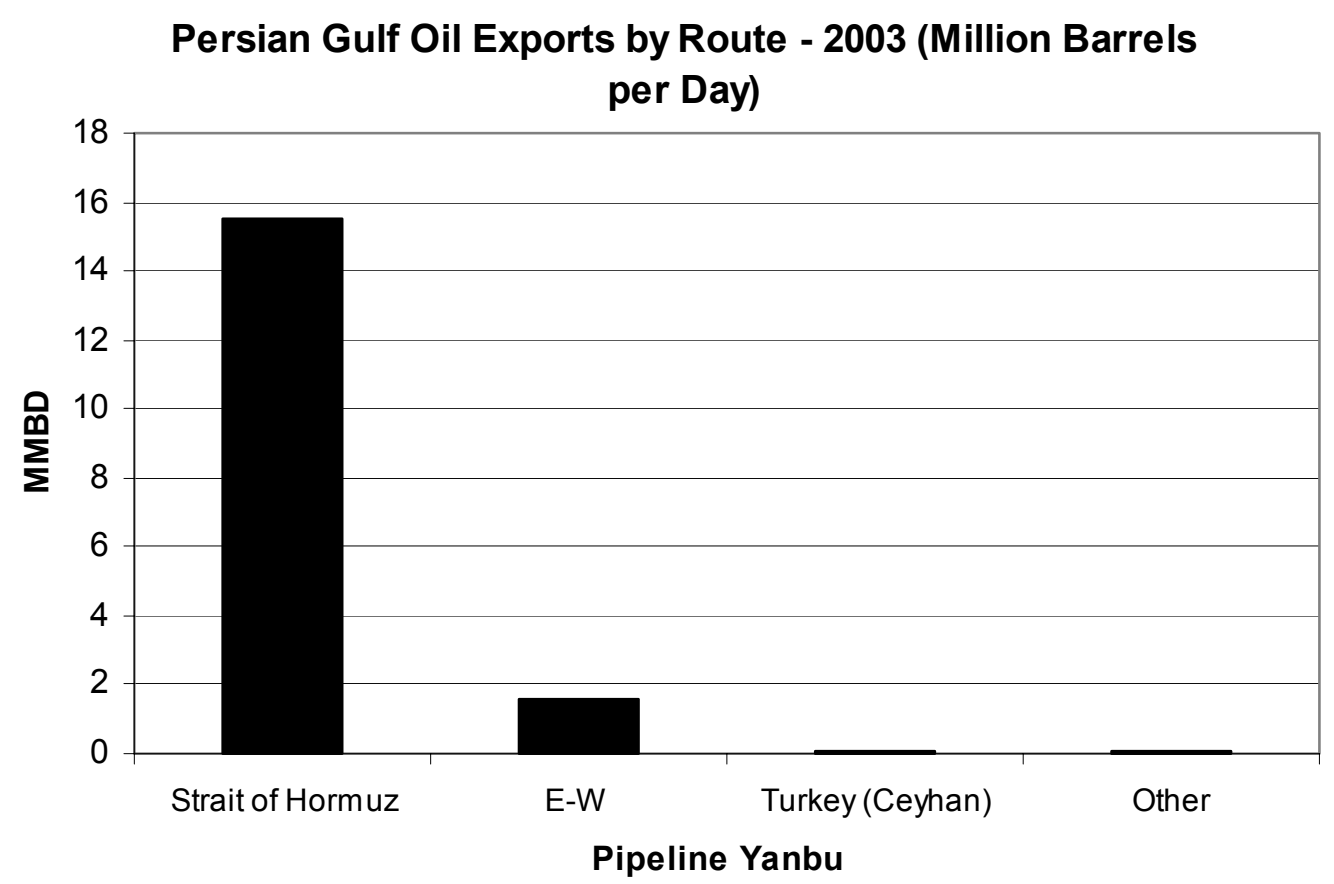

Source: A. Necdet Pamir, "Turkey's Energy Policies between East and West," presentation on February 21, 2006, Bilkent University, http://www.bilkent.edu.tr/ crs/necdetpamir.ppt.

exports (Figure 1). Most of these oil exports leave the Persian Gulf through the Strait of Hormuz; only a very small portion through Turkey (Figure 2). The United States buys a little over 20 percent of its overall oil from the Persian Gulf. ${ }^{63}$ The EU buys 45 percent of its imported oil from Middle East OPEC countries. ${ }^{64}$ The main natural-gas suppliers to both of these Western markets lie outside of the Middle East; however, countries like Iran or Iraq may become important suppliers of gas to the EU. ${ }^{65}$

It is therefore obvious that very little energy exported from the Middle East reaches the West through Turkey. There are currently several projects in place exporting oil and gas from Iran (the Tabriz-
Erzurum pipeline) and Iraq to Turkey. However, due to problems on the supply side, including political and technical impediments and sabotage ${ }^{66}$ these projects cannot carry significant amounts of energy. The situation in these two energy-exporting Gulf countries continues to fluctuate.

Some of the countries in the Middle East (Iran, Egypt, Syria and even Iraq) consider using Turkey as an important transit country to the West. Other major producers, such as Qatar, UAE and Oman, however, remain quite hesitant and have access to other export routes. According to Roberts, these large exporters will decide on using Turkey depending on security developments in Iraq and other parts of the Middle East, the success of the Iranian and 
other pipelines, and the future importance of Turkey as a transit route. ${ }^{67}$ Therefore, although Turkey is a natural energy bridge between the Middle East and Western markets, especially the EU, the geopolitical importance of the country to Middle Eastern producers is not yet certain.

\section{CONCLUSION}

Historically, Turkey has been of significant geopolitical importance to the regions surrounding it as well as to regions and countries further away. ${ }^{68}$ This continues today; the country continues to be of geopolitical significance to many. This importance stems predominantly from its location between large energy markets and major energy producers. With energy demand growing and resources diminishing, large energy consumers like the EU or the United States seek to secure supplies, largely by diversifying their energy suppliers. If Turkey became a major energy transit corridor into the EU, the Union would be able to increase the diversification of its energy suppliers and transit countries to a rather significant extent. Therefore, Turkey is of major geopolitical importance to the EU in terms of energy. An energy transit corridor through Turkey would enable more diversification to the United States as well. Hence, from the energy angle, Turkey is also of substantial geopolitical importance to the United States, although perhaps not of as great importance as it is to the EU.

On the producer side, Turkey is also quite important. Some countries in the landlocked Caspian perceive Turkey as the only export route in their effort to avoid exporting through Russia or Iran. The involvement of Western powers seeking diversification in the Caspian by promoting pipelines through Turkey brings both positives - such as economic aid and military assistance — and negatives such as more instability as a ground for the Great Game.

Turkey is of somewhat lesser importance to the other two exporting regions discussed. Energy pipeline routes and struggles over influence in energy-producing regions fuel rivalry between Russia and Turkey and force Russia to take Turkey's importance into consideration in the geopolitics of the region. Turkey's significance to the Middle Eastern countries from the energy angle is yet to be determined. Although it is a natural energy bridge between the Middle East and Western markets - especially the EU - its geopolitical importance to the Middle East will be ascertained later, based on security developments in Iraq and other parts of the Middle East, the success of the Iranian and other pipelines, and the future importance of Turkey as a transit route.

Geostrategic opportunities as well as hurdles surround Turkey. There have been solid achievements in realizing the EastWest energy corridor through Turkey with the strong encouragement of the United States and, to a lesser extent, the EU. At the same time, the Great Game rivalries in the Middle East and Caspian have been limiting Turkey's potential as a major transit route. Despite these constraints, the country has the potential to make a significant contribution to the security of energy supplies regionally and globally.

${ }^{1}$ Turkey is a net energy importer, currently dependent for almost 65 percent of its energy on imports. This dependency is expected to increase to 75 percent within the next two decades. Zeyno Baran, "The BakuTbilisi-Ceyhan Pipeline: Implications for Turkey," in S. Frederick Starr and Svante E.Cornell, eds., The Baku- 
Tbilisi-Ceyhan Pipeline: Oil Window to the West, (Washington: Central Asia-Caucasus Institute Silk Road Studies Program, 2005) p.103. Such extensive energy dependence can pose a serious strategic threat for Turkey. Because of its considerable dependence on energy imports today and in the future, and because of the increasing importance and scarcity of energy resources in the world, energy has become a fundamental part of Turkey's foreign policy. Emine Kart, “Turkey's Energy Drive: A Journey from Long Gas Lines to the EU's Fourth Artery," Turkish Daily News, Ankara, April 10, 2006.

${ }^{2}$ Baran, "The Baku-Tbilisi-Ceyhan Pipeline," p.103.

${ }^{3}$ Kart, "Turkey's Energy Drive."

${ }^{4}$ See "Baku-Ceyhan Pipeline Opened," http://www.ntvmsnbc.com/news/379678.asp.

${ }^{5}$ Stefan Wagstyl, "EU Gives Blessing to Gas Pipeline," Financial Times, June 26, 2006.

${ }^{6}$ European Commission, "Green Paper: Towards a European Strategy for the Security of Energy Supply."

${ }^{7}$ European Commission, "Green Paper: A European Strategy for Sustainable, Competitive and Secure Energy" (Brussels: Commission of the European Communities, 2006), p.10.

${ }^{8}$ Ibid., p.1.

${ }^{9}$ Axel Krause, "From the Pump to the Plug: Europe's quest for an energy policy," Europe, February 1, 2002, p. 10 .

10 "Energy Policy in the European Union," in EU Guides, March 2005, http://www.eubusiness.com/guides/ energy.

${ }^{11}$ European Commission, "Green Paper: A European Strategy for Sustainable, Competitive and Secure

Energy." p.1.

${ }^{12}$ European Commission, "Energy: Let Us Overcome Our Dependence” (Luxembourg: Office for Official Publications of the European Communities, 2002), p.8.

${ }^{13}$ European Commission, "Green Paper: Towards a European Strategy for the Security of Energy Supply," p. 37.

${ }^{14}$ European Commission, "Green Paper: A European Strategy for Sustainable, Competitive and Secure

Energy," p.13.

${ }^{15}$ European Commission, "Energy: Let Us Overcome Our Dependence,” p. 3.

${ }^{16}$ European Commission, "Green Paper: Towards a European Strategy for the Security of Energy Supply,” p. 2.

${ }^{17}$ Ibid., p. 2

${ }^{18}$ Ibid., p. 22.

${ }^{19}$ Ibid., p. 23.

${ }^{20}$ EU-Turkey Working Paper, Center for European Policy Studies, October 1, 2004, p. 2.

${ }^{21}$ See also Ali Tekin, "Future of Turkey-EU Relations: A Civilisational Discourse,” Futures, Vol. 37, 2005, pp. 299-300.

${ }^{22}$ National Energy Policy Development Group, "Reliable, Affordable, and Environmentally Sound Energy for America’s Future,” May 2001, p. viii, http://www.whitehouse.gov/energy/.

${ }^{23}$ Ibid., p. viii.

${ }^{24}$ Ibid., various pages.

${ }^{25}$ Ibid., various pages.

${ }^{26}$ Ibid., various pages.

${ }^{27}$ Remarks of President Bush to the Capital City Partnership, St. Paul, Minnesota, May 17, 2001, http:// www.whitehouse.gov/news/releases/2001/05/20010517-2.html.

${ }^{28}$ Dinos Stasinopoulos, “The United States New Energy Policy: A European Perspective," Minerals and Energy, Vol. 16, No. 4 (2001), p. 33.

${ }^{29}$ Axel, "From the Pump to the Plug," p. 10.

${ }^{30}$ National Energy Policy Development Group, "Reliable, Affordable, and Environmentally Sound Energy for America's Future," p.4-8. The Group claims that the United States has the good relations with all the four suppliers. Although true in 2001 when the report was written, this cannot be as boldly stated about Venezuela today as the relations between the United States and Chavez's Venezuela have been gradually deteriorating.

${ }^{31}$ Ibid., p. Xv.

32 Ibid. 
Middle East Policy, Vol. XIV, No. 1, SRINg 2007

${ }^{33}$ E. Anthony Wayne, "US-Turkey Relations," Remarks to the American Turkish Council Conference, Washington, DC, March 28, 2006, http://www.state.gov/e/eb/rls/rm/2006/64047.htm.

${ }^{34}$ National Energy Policy Development Group, "Reliable, Affordable, and Environmentally Sound Energy for America's Future," p. 6-8f.

${ }^{35}$ Michael T. Klare, "Geopolitics Reborn: The U.S.-Russian-Chinese Struggle in the Persian Gulf and Caspian Basin," in Blood and Oil: The Dangers and Consequences of America's Growing Dependency on Imported Petroleum, (New York: Metropolitan Books, 2004) p. $147 \mathrm{f}$.

${ }^{36}$ Ibid.,p. 150.

${ }^{37}$ Aylin Guney, “An Anatomy of the Transformation of the U.S.-Turkish Alliance: From 'Cold War' to 'War on Iraq,"” Turkish Studies, Vol.6, No.3, September 2005, p. 346.

${ }^{38}$ Klare, "Geopolitics Reborn: The U.S.-Russian-Chinese Struggle," p. $154 f$.

${ }^{39}$ Ibid., p. 156ff.

${ }^{40}$ National Energy Policy Development Group, "Reliable, Affordable, and Environmentally Sound Energy for America's Future," p. 6-8.

${ }^{41}$ Due to their different history and current situation, Iran and Russia will be discussed later in the paper.

${ }^{42}$ Julian Darley, High Noon for Natural Gas: The New Energy Crisis (White River Junction, Vermont:

Chelsea Green Publishing Company, 2004), p. 112.

${ }^{43}$ Terry Adams, "Caspian Hydrocarbons, the Politicisation of Regional Pipelines, and the Destabilisation of the Caucasus," (Belgium: Centre for European Policy Studies, 2004), p. 1.

${ }^{44}$ Steven R. Mann, Remarks at a Florence IEA Conference, 14 April, 2003, http://www.iea.org/Textbase/work/ 2003/caspian/Mann.pdf.

${ }^{45}$ Interview on EU-Caucasus with Damien Helly conducted by Francois Gremy, 2.11. 2004, http:// www.caucaz.com/home_eng/breve_contenu.php?id=56.

${ }^{46}$ See for example Klare, "Geopolitics Reborn: The U.S.-Russian-Chinese Struggle."

${ }^{47}$ U.S. Library of Congress, Country Studies: Russia, July 1997, http://countrystudies.us/russia/61.htm.

${ }^{48}$ A. Necdet Pamir, "Turkey's Energy Policies between East and West," presentation on February 21, 2006, Bilkent University, http://www.bilkent.edu.tr/ crs/necdetpamir.ppt.

${ }^{49}$ U.S. Library of Congress, Country Studies: Russia.

${ }^{50}$ Energy Information Administration, Russia, no date, http://www.eia.doe.gov/emeu/international/russia.html.

${ }^{51}$ Ibid.

${ }^{52}$ Roberts, "The Turkish Gate," p. 11.

53 “Russia-Turkey Rivalry Wanes," Columbia Daily Tribune, December 5, 2004.

${ }^{54}$ Euractiv, "Turkey-Russia Relations," November 2005, http:/www.euractiv.com/en/enlargement/turkeyrussia-relations/article-134083.

${ }^{55}$ Ibid.

${ }^{56}$ Bulent Aras, "Turkish-Russian Relations: Implications for Eurasia’s Geopolitics," Power and Interest News Report, February 2005, http://www.pinr.com/

report.php?ac=view_printable\&report_id=265\&language_id $=1$.

${ }^{57}$ Roberts, "The Turkish Gate," p. 12.

${ }^{58}$ Ibid., p. 11.

${ }^{59}$ European Commission, “Green Paper: Towards a European Strategy for the Security of Energy Supply,” p. 73.

${ }^{60}$ Discussed in detail in section 3.2.

${ }^{61}$ Roberts, "The Turkish Gate," p.16.

${ }^{62}$ Pamir, "Turkey's Energy Policies between East and West."

${ }^{63}$ Ibid.

${ }^{64}$ European Commission, “Green Paper: Towards a European Strategy for the Security of Energy Supply,” p. 2.

${ }^{65}$ Gareth M. Winrow, "Turkey and the East-West Gas Transportation Corridor," Turkish Studies, Vol. 5,

No.2, Summer 2004, p. 39.

${ }^{66}$ Pamir, "Turkey's Energy Policies between East and West."

${ }^{67}$ Roberts, "The Turkish Gate," p. 5.

${ }^{68}$ Tekin, "Future of Turkey-EU Relations," pp. 287-89 and 299-300. 